\title{
THE INFLUENCE OF HEAT TREATMENT TIME AND TEMPERATURE ON THE PHYSICAL PROPERTIES OF ASSAB-CORAX STEEL
}

\author{
Aziz K. Jahja, Parikin and Nurdin Effendi \\ Centre for Nuclear Industrial Materials Technology, \\ National Nuclear Energy Agency \\ Kawasan Puspiptek Serpong Tanggerang, Indonesia 15314
}

\begin{abstract}
THE INFLUENCE OF HEAT-TREATMENT TIME AND TEMPERATURE ON THE THERMO-PHYSICAL PARAMETERS OF ASSAB-CORAX STEEL. X-ray diffraction experiment was carried out on commercial Assab-Corax steel sample. The polished samples are then heated to various temperature for different holding time; $200{ }^{\circ} \mathrm{C}$ for 4 hours, $300{ }^{\circ} \mathrm{C}$ for 4 hours, $400^{\circ} \mathrm{C}$ for 6-, 8-, 12 - and 16 hours, $500{ }^{\circ} \mathrm{C}$ for 4 hours and $600{ }^{\circ} \mathrm{C}$ for 4 hours. The refinement of the diffraction intensity was carried out using the $\operatorname{Im} 3 \mathrm{~m}$ model, and the results show that the Carbon atoms are distributed among the base position in the body centered cubic unit cell at the eight-fold octahedral interstitial sites. Using the refined structural parameters, thermo-physical properties such as Debye temperature and coefficient of thermal expansion are calculated. From the results of the analysis it could be concluded that Debye temperature in Assab-Corrax steels tend to decrease with increasing heat-treatment time but tend to increase with heat treatment temperature. The coefficients of linear expansion also tend to decrease with increasing heat-treatment time and tend to increase with heat treatment temperature. Although the patterns are different, for example when the Debye temperature reaches its peak value for heat treatment time of 8 hours, the coefficient of linear expansion would reach its low point at this time. Therefore, the general finding is that both treatmenttemperature and - time are influential to the physical properties of Assab-Corrax steels and xray diffraction methods could be utilized in elucidating these important findings.
\end{abstract}

Keywords: Assab-Corrax steel, X-ray diffraction, Debye temperature, Rietveld refinement

\section{INTRODUCTION}

Assab-Corrax steel forms one of the most important steel products available in the current market and is a product of ASSAB STEEL Germany. In the general spec-sheet issued by the company, the steel is classified as plastic mould steel with high corrosion resistance and medium scratch capacity [1]. The chemical composition of this steel is tabulated in table 1.

Table 1. Chemical composition of Assab-Corrax steel [1].

\begin{tabular}{|l|c|c|c|c|c|c|c|}
\hline Element & $\mathrm{C}$ & $\mathrm{Cr}$ & $\mathrm{Mo}$ & $\mathrm{Mn}$ & $\mathrm{Si}$ & $\mathrm{Ni}$ & $\mathrm{Al}$ \\
\hline Content (at\%) & 0.03 & 12.30 & 1.40 & 0.03 & 0.30 & 9.2 & 1.6 \\
\hline
\end{tabular}

In this work the variation of thermo physical properties with heat-treatment time is reported, after the samples were heat-treated for $6,8,12$ and 16 hours. The high $\mathrm{Ni}$ and $\mathrm{Al}$ content is the reason why this type of steel is hightemperature resistant, and highly suitable for high temperature operations. 
The properties of steels, determined by dispersion strengthening, depend on the amount, size, shape and distribution of cementite. Isothermal heat treatments, usually used in combination with other heat treatment such as tempering, for example to form martensite. Heat-treatment and temper heat treatments require the formation and decomposition of martensite, providing exceptionally fine dispersions of $\mathrm{Fe}_{3} \mathrm{C}$ [2]. A heat-treatment and temper heat treatments provides a microstructure that can provide both strength and toughness. Earlier, Mohan-Rao et al. [3], and Morinaga et al.[4] carried out studies on the influence of the addition of $\mathrm{Hf}, \mathrm{Zn}$ and Ti on the Debye-Waller factors and Debye temperature of $\mathrm{Ni}_{3} \mathrm{Al}$ alloys using X-ray diffraction Rietveld method. X-ray diffraction Rietveld method is also employed for example to investigate the physical properties of Al-Li alloys [5]. However, no data or information is available on the behaviour of Assab steels in the post-heat-treatment pre-tempering conditions, especially with regards to changes in the thermo-physical properties such as Debye temperature and coefficient of thermal expansion [6]. Therefore, it is necessary to investigate these properties regarding its application as high temperature component of nuclear power-plant turbine, located in the first zone (zone I) and extending out to the tertiary zone (zone III) of the power plant [7].

\section{THEORY}

\section{Physical Metallurgy of Assab-Corrax Steel}

As mentioned in the introduction, Assab-Corrax belongs to a group of low carbon steel. Low carbon steel transforms back to BCC structure at lower temperature; this structure is called $\alpha$ - or ferrite-phase [8a,b]. Heat-treatment is one of the oldest methods to increase the strength and hardness of steel. In $\alpha$-steels (ferrite), the $\mathrm{C}$ atoms is located on the edges of the cube, at the eightfold octahedral Wyckoff sites (8c). Therefore by heat-treatment or rapid heat-treatment, no $\mathrm{Fe}_{3} \mathrm{C}$ precipitate could be formed by insoluble $\mathrm{C}$. The $\mathrm{C}$ remains in the lattice, but at the same time distorts the lattice simply, and this in turns could increase the strength and hardness of the steel, because the high stress induced during the samples' fabrication and heat treatment would block the propagation of the dislocation in the steel.

\section{Thermo-physical Theory of Solids}

\section{Debye Temperature}

Debye temperature $\Theta_{D}$ is associated with diverse physical properties of a solid alloy such as molar heat capacity, melting temperature and sound velocity in a solid [7], among other things. According to solid-state theory, the temperature factor $B$ can also be expressed as, 


$$
B=\left(6 h^{2} / m k T\right) W(x)
$$

Where $m$ is the mass and $T$ is the absolute temperature. The function $W(x)$ is given by,

$$
W(x)=\left[\varphi(x) /\left(x^{2}\right)+(x / 4)\right]
$$

Where $\varphi(x)$ is the Debye integral function and $x=\Theta_{\mathrm{D}} / T$. Based upon Debye approximation, equation (5) is subtituted into equation (4), so that equation (4) could be rewritten as,

$$
m_{M} B=6 h^{2} / k T\left\{\varphi(x) /\left(x^{2}\right)+(x / 4)\right\}
$$

Here $m$ is replaced by $m_{M}$, the mass of the virtual chemical species in terms of the nominal mole-fractions.

The Debye integral function $\varphi(x)$ could be approximated by the following polynomial [7b],

$$
\left\{\varphi(x) /\left(x^{2}\right)+(x / 4)\right\}=1+\frac{x^{2}}{36}-\frac{x^{4}}{3600}+\ldots \ldots \ldots \ldots \ldots+\text { (higher order terms) }
$$

Therefore, equation (6) to a certain approximation could be written as,

$$
\frac{1}{36}+\frac{x^{2}}{3600}-x^{4}=G x^{2}
$$

Here $G$ is given by $\left(k T / 6 h^{2}\right) m_{M} B$, and therefore using regression analysis the value of $\Theta_{\mathrm{D}}$ for Ni25at.\% $\mathrm{Cr}$ alloys could be calculated by solving the transcendental equation (5), as presented in figure 4.

\section{Coefficient of linear expansion $\alpha_{L}$ estimation}

For $T \gg \Theta_{\mathrm{D}}$ the average amplitude vibration is given by the expression,

$$
<u_{\mathrm{ii}}>=3 / 4 M / L^{2} k_{\mathrm{B}} T
$$

Here $L, M$ are coefficients related to the bonding energies of ions in the sample, $L$ is related to the harmonic oscillation term, $a_{0}$ is the lattice parameter and $M$ is related to the anharmonic oscillation term. Moreover, the coefficient of thermal expansion is given by,

$$
\alpha_{\mathrm{L}}=3 / 4\left(M / L^{2}\right) k_{\mathrm{B}} / a_{\mathrm{o}}
$$

\section{EXPERIMENTAL METHOD}

Assab-Corrax steel samples of German fabrication were obtained commercially from the market (P.T. Assab-Corrax Indonesia). The samples were cut into several pieces, are then polished using sand-paper with grids 
ranging from very coarse to very fine , i.e. $80,100,150,200,320,400,600$, $800,1000,1500$ and 2000 until the desired surface's smoothness is obtained and also in compliance with the standard protocols in $\mathrm{x}$-ray diffraction measurements. All experimental work was carried out at BBIN-PTBIN laboratory.

\section{Heat Treatment}

The heat-treatment was carried out manually, meaning that the furnace is set up manually and the samples are inserted and taken out from the furnace by hand. The first step in the age-hardening heat treatment is heat-solution treatment. The alloy is heated above the solvus temperature to dissolve any second phase and to produce a homogenous single-phase structure. The samples undergone heat-solution treatment at about $900{ }^{\circ} \mathrm{C}$, before quenching. The quenched samples are then heated to various temperature for different holding time; $200{ }^{\circ} \mathrm{C}$ for 4 hours, $300{ }^{\circ} \mathrm{C}$ for 4 hours, $400{ }^{\circ} \mathrm{C}$ for $6-, 8-, 12-$ and 16 hours respectively, $500{ }^{\circ} \mathrm{C}$ for 4 hours and $600{ }^{\circ} \mathrm{C}$ for 4 hours.

\section{X-ray diffraction}

Resin as a glue-material were first added to the heat-treated samples. The samples mounted in the XRD-sample holder before exposure to the radiation of the $\mathrm{x}$-ray diffraction apparatus. Diffraction intensity was measured using the PTBIN-BATAN Shimadzu X-Ray Diffractometer, by step counting method with a $0.05^{\circ}$ step-scan and the preset time of 2 seconds. Using the collected experimental data, the background, the scale-factor and phase-dependent parameters were refined using the leastsquares method of the Rietan program [9].

\section{RESULTS AND DISCUSSION}

\section{Crystal Structure Investigation}

In Figure 1, the continuous counting diffraction pattern of untreated Assab-Corax sample is presented. From Figure 1 the unit cell parameters are calculated using the nominal wavelength of the x-ray diffraction and the results compared to the literature [1]. The experimental parameters will be used as the initial (guessed) input parameters in the Rietveld refinement procedures. It was evident from the initial (manual) analysis of the cell parameters that the crystal structure of the sample phase is based on a bodycentered-cubic (bcc) unit cell. In Table 2. Structural parameters of the preheat-treatment and heat-treatmented Assab-Corrax samples are presented. 
Table 2. Structural parameters of Assab-Corrax steel heat-treated for various time and different temperature

\begin{tabular}{|c|c|c|c|c|c|c|c|c|c|c|c|c|c|c|c|c|}
\hline (hkl) & \multicolumn{10}{|c|}{ Relative $\mathrm{I}_{\mathrm{o}}$ (counts) } & \multicolumn{10}{c|}{ FWHM } \\
\cline { 2 - 15 } & T24 & T34 & T412 & T416 & T46 & T48 & T54 & T64 & T24 & T34 & T412 & T416 & T46 & T48 & T54 & T64 \\
\hline$(110)$ & 10000 & 10000 & 10000 & 10000 & 10000 & 10000 & 10000 & 10000 & 0.3352 & 0.3684 & 0.3392 & 0.3607 & 0.2839 & 0.3078 & 0.3229 & 0.3229 \\
$(200)$ & 8187 & 13401 & 11277 & 21164 & 13018 & 16644 & 9039 & 9039 & 0.5724 & 0.5243 & 0.4669 & 0.5758 & 0.5009 & 0.4366 & 0.5494 & 0.5494 \\
$(211)$ & 14652 & 26522 & 19416 & 37821 & 25830 & 29579 & 17241 & 17241 & 0.8455 & 0.7294 & 0.6589 & 0.8499 & 0.7405 & 0.6185 & 0.8616 & 0.8616 \\
$(220)$ & 6901 & 14500 & 9946 & 13754 & 12389 & 10084 & 13882 & 13882 & 1.1255 & 0.9362 & 0.8554 & 1.1358 & 0.9732 & 0.7940 & 1.200 & 1.200 \\
$(310)$ & & 19583 & 14366 & 22634 & 17737 & 16557 & 11706 & 11706 & & 1.2861 & 1.1975 & 1.6016 & 1.3490 & 1.1020 & 1.7459 & 1.7459 \\
\hline
\end{tabular}

It is evident from the results of X-ray diffraction continuos counting experiment in Figure 1 that the sample, in both the untreated and the heattreated condition, is in the ferrite (single) phase and has a body-centeredcubic structure, so it is preferred to employ the bcc structure model represented by the $\mathrm{Im} 3 \mathrm{~m}$ space group. Therefore in the refinement process it was assumed that in both conditions (pre-heat-treatment and heat-treatment), the sample has the same phase, i.e. crystallographically modeled using the bcc structure model, with the $\mathrm{C}$ atoms positioned at interstitial octahedral sites. Employing the specially developed computer application code RIETAN attributed to F. Izumi [9], the refinement of the x-ray diffraction intensity is proceeded. Pseudo-Voigt profile function and conjugate-direction iteration method was used in the refinement process. Refined parameters include global parameters, background and shift parameters, and phase-dependent parameters, in this case preferred orientation, lattice parameter and isotropic thermal factor.

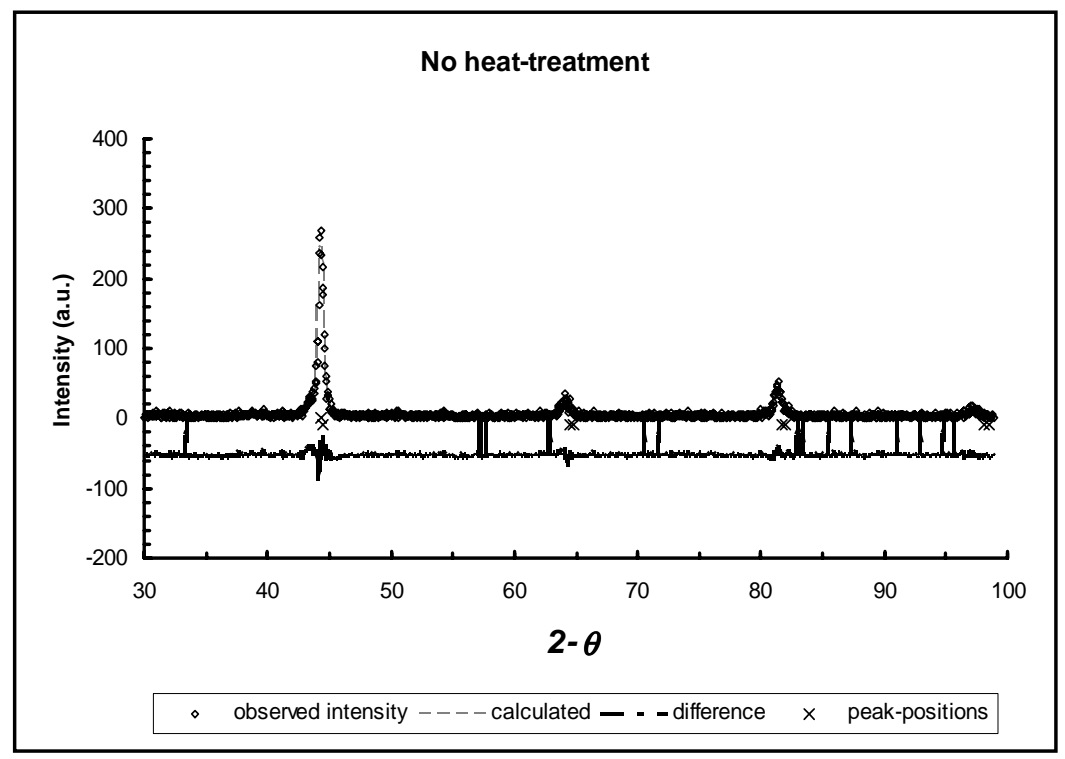

Figure 1. Refined diffraction pattern of untreated Assab-Corrax steel. 


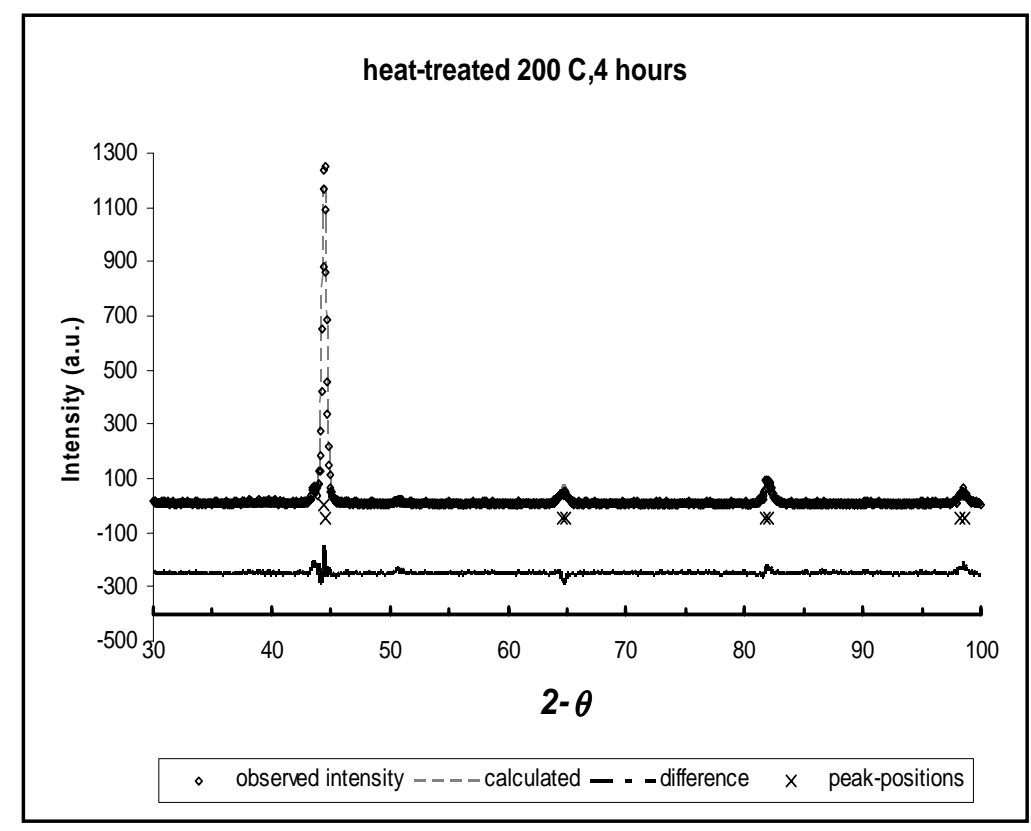

Figure 2. Refined diffraction pattern of Assab-Corrax steel heat-treated at $200{ }^{\circ} \mathrm{C}$ for four hours.

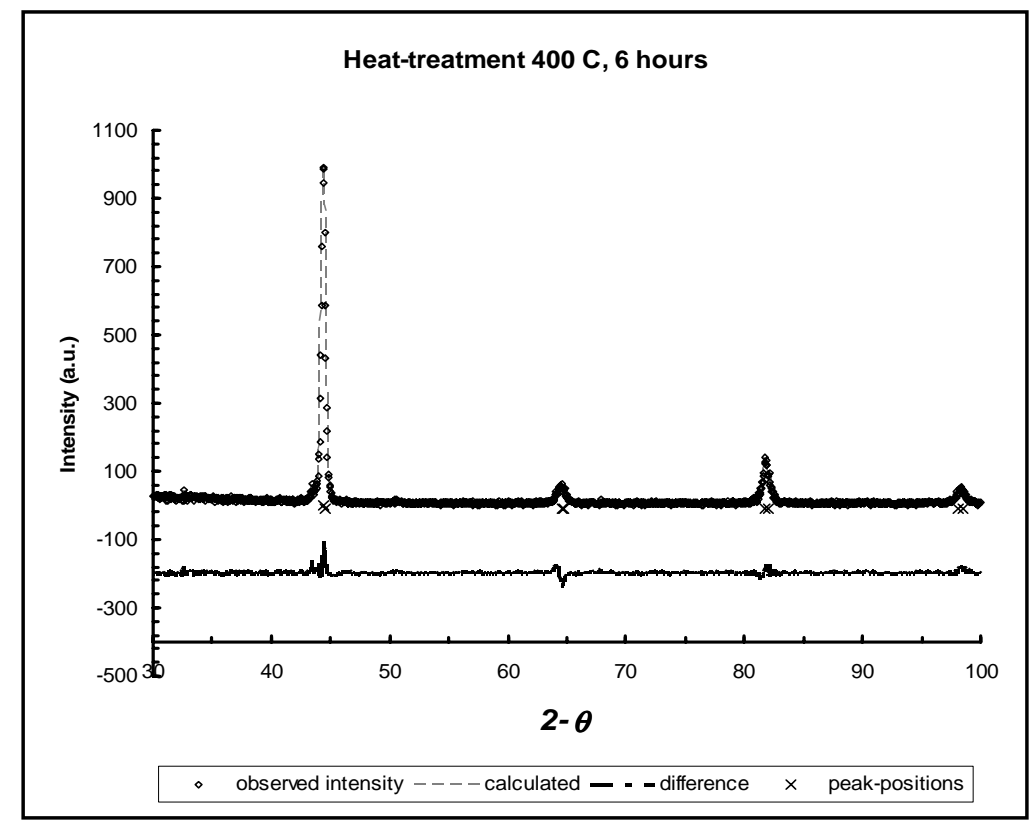

Figure 3. Refined diffraction pattern of Assab-Corrax steel heat-treated at $400{ }^{\circ} \mathrm{C}$ for six hours. 


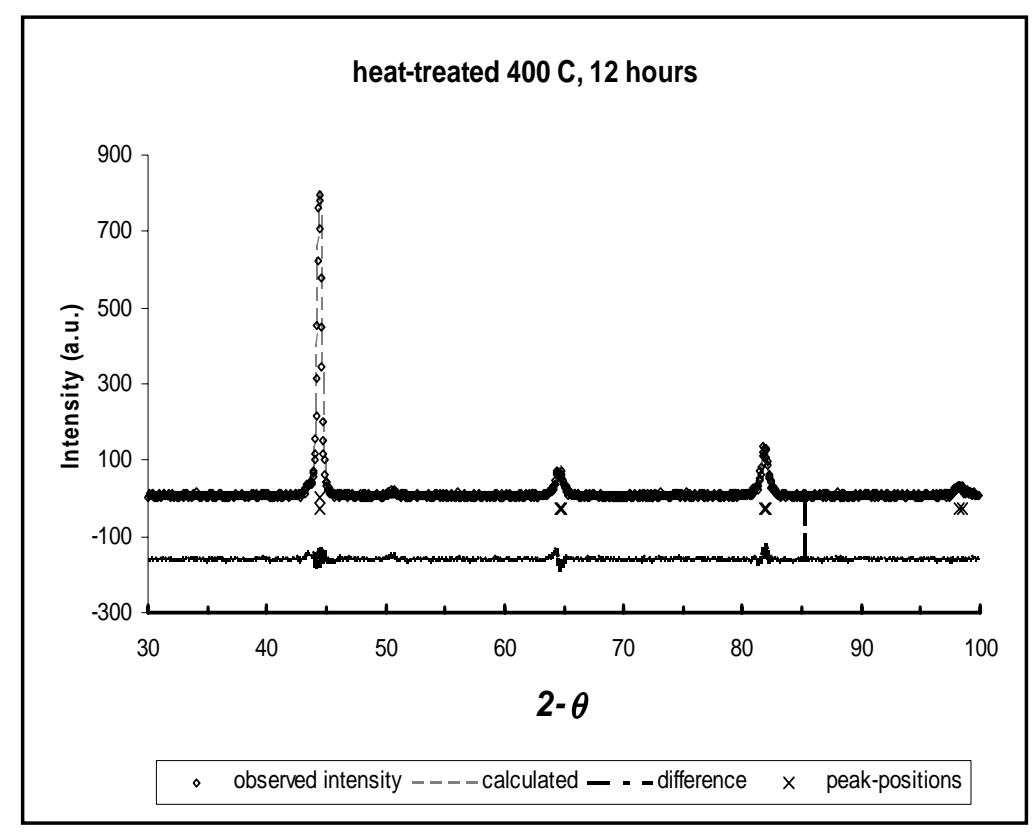

Figure 4. Refined diffraction pattern of Assab-Corrax steel heat-treated at $400{ }^{\circ} \mathrm{C}$ for twelve hours.

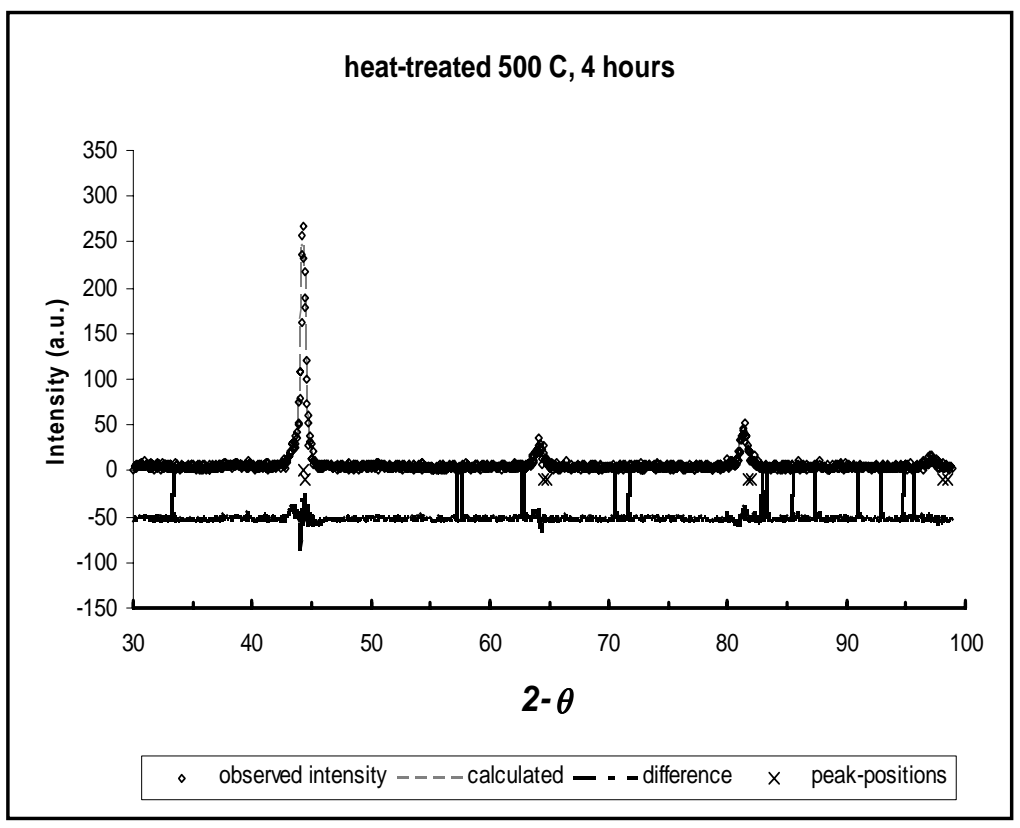

Figure 5. Refined diffraction pattern of Assab-Corrax steel heat-treated at $500{ }^{\circ} \mathrm{C}$ for four hours. 


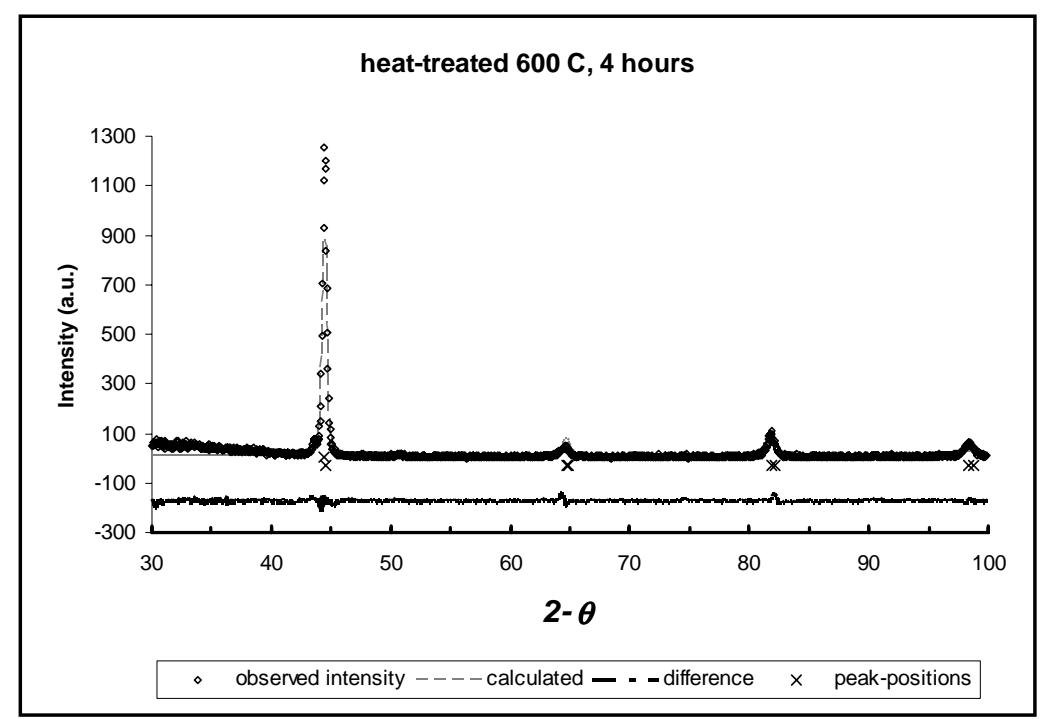

Figure 6. Refined diffraction pattern of Assab-Corrax steel heat-treated at $600{ }^{\circ} \mathrm{C}$ for four hours.

Results of Rietveld refinement are presented in Figures 1 through 6. The observed, the calculated (refined) intensity and the refinement residuals are presented for the various heat-treatment conditions.

Table 3. Refined structural Parameters Lattice parameter a Debye-Waller factor B, isotropic vibration amplitude $\mathrm{u}_{\mathrm{ii}}$ of Assab-Corrax steel heattreated for different time and temperature

\begin{tabular}{|c|c|c|c|c|c|c|c|c|}
\hline \multicolumn{9}{|c|}{$\begin{array}{c}\left.\text { Phase }^{* * *}\right) \\
\text { M } \\
(\mathrm{Fe}-\mathrm{Ni}-\mathrm{Cr})\end{array}$} \\
\hline $\begin{array}{c}\text { Heat- } \\
\text { treatment- } \\
\text { Condition }^{*} \text { ) }\end{array}$ & $\begin{array}{c}\text { Lattice } \\
\text { parameter } \\
\left.a(\AA)^{* * *}\right)\end{array}$ & $\begin{array}{c}B \\
\left(\AA^{2}\right)\end{array}$ & $\begin{array}{c}\left\langle u_{i i}\right\rangle \\
(\AA)\end{array}$ & $\begin{array}{l}\mathrm{R}_{\mathrm{wp}} \\
(\%)\end{array}$ & $\begin{array}{c}\mathrm{R}_{\mathrm{p}} \\
(\%)\end{array}$ & $\begin{array}{c}\mathrm{R}_{\mathrm{F}} \\
(\%)\end{array}$ & $\begin{array}{l}\mathrm{R}_{\mathrm{I}} \\
(\%)\end{array}$ & $\begin{array}{l}\text { "Goodness } \\
\text { of Fit S" }\end{array}$ \\
\hline T00 & $2.884(4)$ & 0.5777 & 0.086 & 20.87 & 20.15 & 11.42 & 15.60 & 1.074 \\
\hline $\mathrm{T} 24$ & $2.878(7)$ & 2.9244 & 0.192 & 21.84 & 21.51 & 9.13 & 10.01 & 1.356 \\
\hline T34 & $2.884(2)$ & 0.2994 & 0.067 & 27.14 & 26.87 & 7.72 & 11.41 & 1.202 \\
\hline T46 & $2.884(1)$ & 0.4742 & 0.077 & 22.76 & 22.95 & 8.32 & 12.54 & 1.267 \\
\hline $\mathrm{T} 48$ & $2.882(1)$ & 0.2348 & 0.055 & 22.86 & 17.16 & 7.08 & 10.00 & 1.118 \\
\hline $\mathrm{T} 412$ & $2.883(1)$ & 0.7365 & 0.097 & 29.88 & 20.99 & 6.19 & 9.20 & 1.214 \\
\hline T416 & $2.884(2)$ & 0.0830 & 0.032 & 23.00 & 22.93 & 5.57 & 7.13 & 1.219 \\
\hline T54 & $2.882(1)$ & 0.7012 & 0.094 & 21.21 & 21.43 & 12.54 & 15.53 & 1.407 \\
\hline T64 & $2.878(1)$ & 0.0746 & 0.031 & 22.70 & 15.47 & 4.32 & 5.73 & 1.178 \\
\hline
\end{tabular}

$\left.{ }^{*}\right)$ T00: No heat treatment, T24: Heat treatment at $200{ }^{\circ} \mathrm{C}$ for 4 hours; T34: Heat treatment at $300{ }^{\circ} \mathrm{C}$ For 4 hours; T46: Heat treatment at $400{ }^{\circ} \mathrm{C}$ for 6 hours; T48: Heat treatment at $400{ }^{\circ} \mathrm{C}$ for 8 hours; T412: Heat treatment at $400{ }^{\circ} \mathrm{C}$ for 12 hours; T416: Heat treatment at $400{ }^{\circ} \mathrm{C}$ for 16 hours; T54: Heat treatment at $500{ }^{\circ} \mathrm{C}$ for 4 hours; T64: Heat treatment at $600{ }^{\circ} \mathrm{C}$ for 4 hours

${ }^{* *}$ An imaginary chemical species $\mathrm{M}(\mathrm{Fe}-\mathrm{Ni}-\mathrm{Cr})$ was input.

$\left.{ }^{* * *}\right)$ Numbers in parentheses indicate standard deviation in the last significant digit of refined parameters. SG. Im3m (vol. I-229); 1601 data points, five reflections (110), (200), (211), (220) and (310). 
The refinement results are shown in Table 3. The lattice parameter $a$ and isotropic temperature factor $B$ are shown with the reliability indices (R factors). Debye-Waller factor $B$, Debye temperature $\Theta_{\mathrm{D}}$, Debye frequency and isotropic vibration amplitude $u_{\mathrm{ii}}$ of Assab-Corrax alloy is presented in Table 4. Debye temperature of Assab-Corrax steel as a function of heattreatment time for heat-treatment temperature $400^{\circ} \mathrm{C}$, and Debye temperature of Assab-Corrax steel as a function of heat-treatment temperature for heattreatment time of 4 hours are presented in Figures 7 and 8 respectively.

Table 4. Debye-Waller factor $B$, Debye temperature $\Theta_{\mathrm{D}}$, Debye frequency and isotropic vibration amplitude $u_{\mathrm{ii}}$ of Assab-Corrax alloy

\begin{tabular}{|c|c|c|c|c|}
$\begin{array}{c}\text { Phase } \\
\text { M (Fe-Ni-Cr) }\end{array}$ & $\begin{array}{c}B \\
\left(\AA^{2}\right)\end{array}$ & $\begin{array}{c}\Theta_{\mathrm{D}} \\
(\mathrm{K})\end{array}$ & $\begin{array}{c}v_{\mathrm{D}} \\
\left(10^{12} \mathrm{~Hz}\right)\end{array}$ & $\begin{array}{c}u_{\mathrm{ii}} \\
(\AA)\end{array}$ \\
\cline { 1 - 4 } Condition & 0.5777 & 234 & 4.88 & 0.086 \\
T00 & 0.5244 & 103 & 2.15 & 0.192 \\
T24 & 2.9244 & 0.062 \\
T34 & 0.2994 & 327 & 6.82 & 0.062 \\
T46 & 0.4742 & 259 & 5.40 & 0.078 \\
T48 & 0.2348 & 372 & 7.75 & 0.055 \\
T412 & 0.7365 & 207 & 4.31 & 0.097 \\
T416 & 0.0830 & 194 & 4.04 & 0.032 \\
T54 & 0.7012 & 211 & 4.40 & 0.094 \\
T64 & 0.0746 & 644 & 13.42 & 0.031 \\
& & & & \\
\hline
\end{tabular}

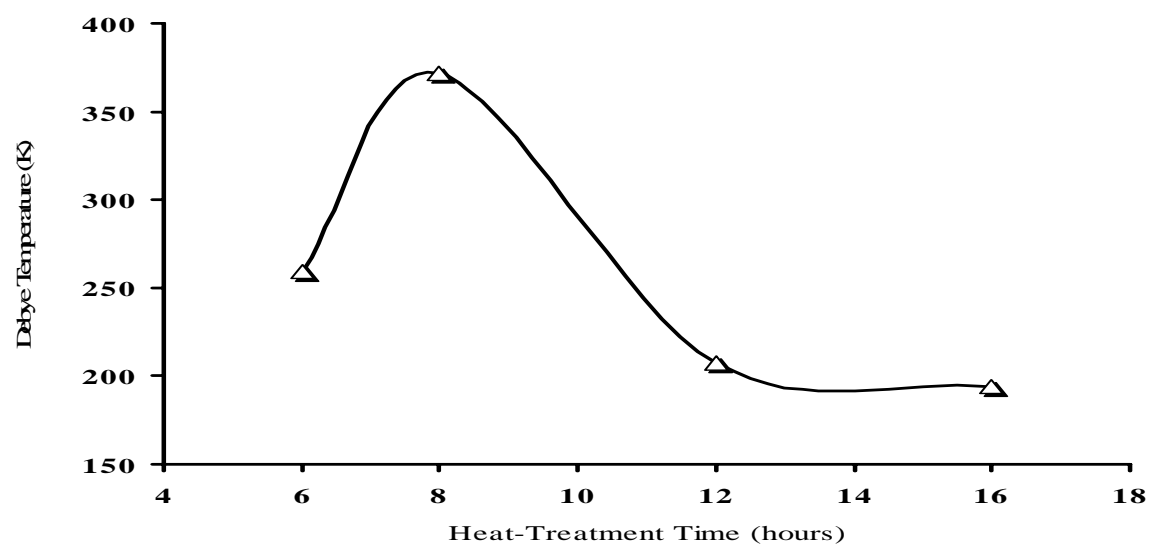

Figure 7. Debye temperature of Assab-Corrax steel as a function of heattreatment time for heat-treatment temperature $400{ }^{\circ} \mathrm{C}$. 


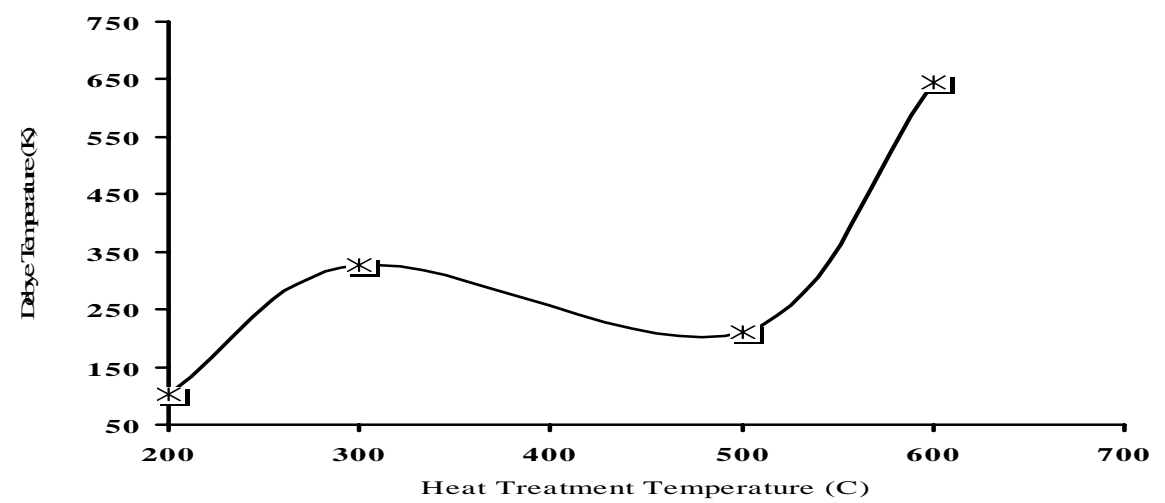

Figure 8. Debye temperature of Assab-Corrax steel as a function of heattreatment temperature for heat-treatment time of 4 hours.

\section{Calculation of Thermal Expansion Coefficient}

Using data from Table 1 and Table 4, equations (11) and (12) the values $M / L^{2}$ and $\alpha_{\mathrm{L}}$ could be calculated, and compared with other elements as presented in Table 5.

Table 5. Calculated $M / L^{2}$ and microscopic $\alpha_{\mathrm{L}}$ of Assab-Corrax to experimental values of macroscopic $\alpha_{\mathrm{L}}[6]$.

\begin{tabular}{|c|c|c|}
\hline Elements, alloys & $\boldsymbol{M} / \boldsymbol{L}^{2}\left(10^{-3} \AA / \mathrm{meV}\right)$ & $\alpha_{\mathrm{L}} \times 10^{-5} / \mathrm{K}$ \\
\hline T00 & 2.147 & 3.484 \\
T24 & 4.792 & 7.805 \\
T34 & 1.55 & 2.515 \\
T46 & 1.95 & 3.164 \\
T48 & 1.375 & 2.236 \\
T412 & 2.425 & 3.644 \\
T416 & 0.8 & 1.298 \\
T54 & 2.35 & 3.813 \\
T64 & 0.775 & 3.694 \\
Ni (25 $\left.100{ }^{\circ} \mathrm{C}\right)$ & & 1.33 \\
Cr & & 0.62 \\
304 SS & & 1.73 \\
308 Al Alloy & & 2.01 \\
Constantant & & 2.36 \\
Solder material (50Pb-50 Sn) & & 1.46 \\
\hline
\end{tabular}

Coefficient of linear expansion of Assab-Corrax steel as a function of heattreatment time for heat-treatment temperature of $400{ }^{\circ} \mathrm{C}$ and coefficient of linear thermal expansion of Assab-Corrax steel as a function of heattreatment temperature for heat-treatment time of 4 hours, are presented in Figures 9 and 10 respectively. 


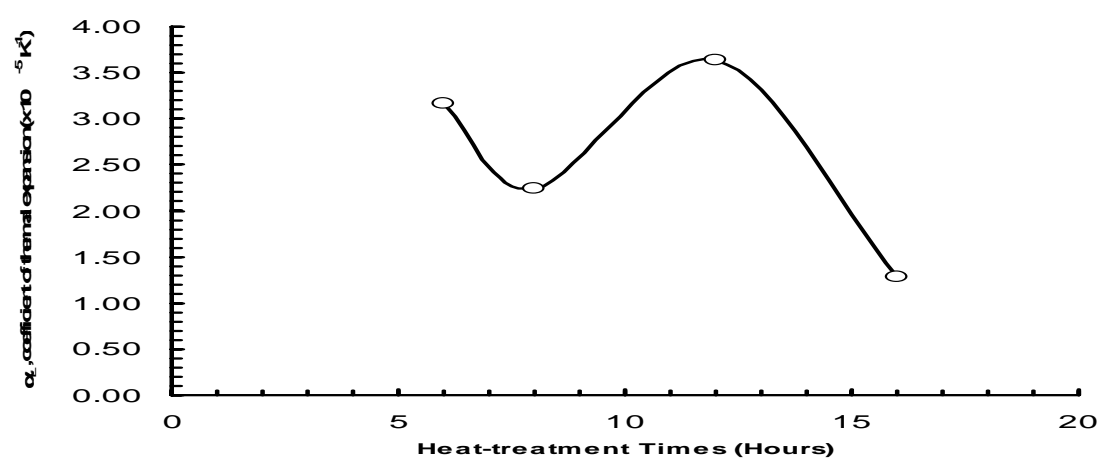

Figure 9. Coefficient of linear expansion of Assab-Corrax steel as a function of heat-treatment time for heat-treatment temperature of $400{ }^{\circ} \mathrm{C}$.

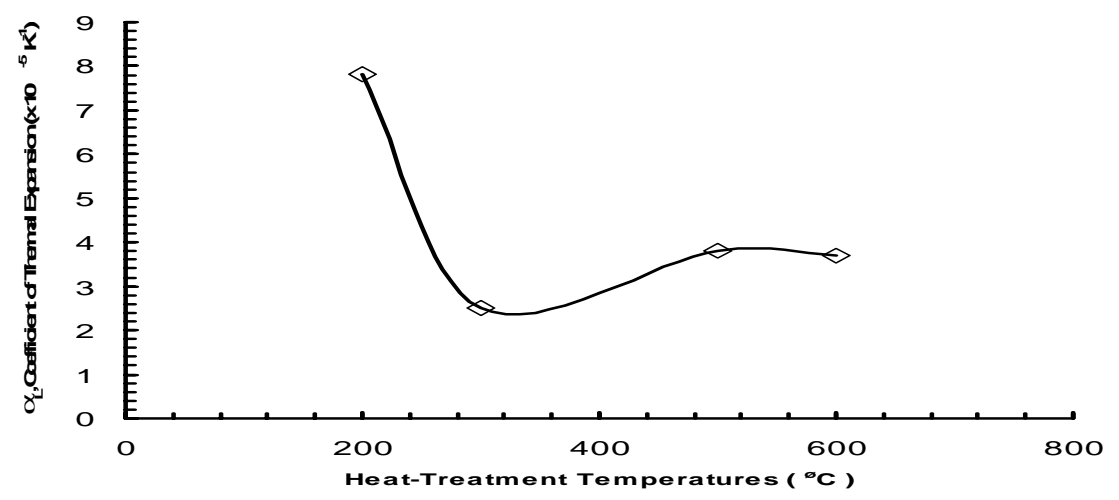

Figure 10. Coefficient of linear thermal expansion of Assab-Corrax steel as a function of heat-treatment temperature for heat-treatment time of 4 hours.

One could explanation the results is that the Debye-Waller (D-W) factor composed of a static and a dynamic component. The longer the heattreatment time, the larger the lattice strain introduced from the static D-W factor, and therefore the Debye temperature do not result from just latticevibration alone, and this causes an abnormal decrease in Debye temperature. On the other hands the coefficients of linear expansion also tend to decrease with increasing heat-treatment time but tend to increase with heat treatment temperature. Although the patterns are different, for example when the Debye temperature reaches its peak value for heat treatment time of 8 hours (see figure 7), the coefficient of linear expansion reaches its low (figure 9). 


\section{CONCLUSION}

The general finding is that there is at least qualitative evidence that both treatment-temperature and - time are influential to the physical properties of Assab-Corrax steels and x-ray diffraction methods could be and should be utilized in elucidating these important findings. Experimental evidence and subsequent analysis show that qualitatively Debye temperature in Assab-Corrax steels tend to decrease with increasing heat-treatment time but tend to increase with heat-treatment temperature.

\section{ACKNOWLEDGEMENT}

The authors would like to express their gratitude to Drs. Gunandjar, S.U., head of P3IB-BATAN, for his valuable support and for suggesting this project, so that this programme could be carried out. Gratitude is also due to Mr. Drs. Bambang H. Pranowo, project manager for the 2004 fiscal year at P3IB-BATAN for the financial support.

\section{REFERENCES}

1. "Assab-Corrax General Specification Sheet", Assab-Corrax Gmbh (2003)

2. B. ADJIANTORO, J. Kond. Pdt., $\underline{5}$ (1) ( 2004) 21-28

3. R.V. MOHAN RAO, K. SATYANARAYANA MURTHY, S.V. SURYANARAYANA AND S.V. NAGENDHER NAIDU, J. App. Cryst., 26(5) (1993) 670-676

4. M. MORINAGA, K. SONE, T. TAMIMURA, K. OHTAKA AND N. YUKAWA, J. App. Cryst., 21 (1988) 41-46

5. J.I. PEREZ-LANDZABEL, M.L. NO, G. MADARIAGA AND J. SAN JUAN, J. App. Cryst., $\underline{30}$ (1997) 107-113

6. Ferritic Stainless Steels - Mechanical Properties, download: Knight Strip Metals, 2005, - http:/ www.knight-group.co.uk-

7. A. F. FOSTER AND R. R. WRIGHT Jr., "Basic Nuclear Engineering", Allyn and Bacon Inc. Boston London Sydney second edition (1975)

8. a. "ASM Volume 3 Alloy Phase Diagram", the Mater. Information Society (1990)

b. P. VILLARS AND L.D. CALVERT, "Pearson`s Handbook of Crystallographic Data for Intermetallic Phases", ASM International $2^{\text {nd }}$ edition volume 2 B (1991)

9. F. IZUMI, J. Mineral Soc. Japan, 17 (1985) 37 